\title{
Spatial Genetic Structure and Life History Traits in Cerrado Tree Species: Inferences for Conservation
}

\author{
Rosane Garcia Collevatti*, Jacqueline Silva Lima, Thannya Nascimento Soares \& \\ Mariana Pires de Campos Telles
}

Laboratório de Genética e Biodiversidade, Departamento de Biologia Geral, Instituto de Ciências Biológicas, Universidade Federal de Goiás - UFG, CP 131, CEP 74001-970, Goiânia, GO, Brasil

\begin{abstract}
Spatial Genetic Structure (SGS) is correlated with life history traits and is affected by ecological and demographic processes. We discuss here the SGS within populations of three species from Cerrado Biome, Caryocar brasiliense, Dipteryx alata and Tibouchina papyrus, which vary in life history traits. Our working hypothesis was that self-incompatible and wind-dispersed species present no SGS due to long distance pollen gene flow. SGS analyses were based on polymorphism at microsatellite loci. Weak SGS was found for the three species, but the mammal dispersed species, $C$. brasiliense and $D$. alata, presented stronger SGS than the wind dispersed species. T. papyrus. Although $D$. alata presented the highest value of $S_{p}$ (intensity of SGS), breeding system was not related with SGS because the other two self-compatible species presented contrasting patterns of SGS. The three species may be highly affected by fragmentation, especially the wind-dispersed species T. papyrus, due to endemism and habitat vulnerability.
\end{abstract}

Key words: Spatial Genetic Structure, Kinship, Life History, Cerrado.

\section{Introduction}

The spatial genetic structure (SGS) is the non-random distribution of genotypes within a population (Vekemans and Hardy 2004) as the outcome of gene flow, genetic drift and selection (Wright 1943). SGS is affected by ecological processes (e.g. Born et al. 2008) such as recent colonization events and density of maternal seed sources that may foster SGS within populations (Jones et al. 2005). SGS is also affected by life history characteristics, including variation in breeding system, life form (see Vekemans \& Hardy and references therein) and seed dispersal mode (e.g. Hardy et al. 2006).

In a more explicitly biological conservation context, habitat fragmentation and disturbance may change the spatial genetic structure due to disruptions in ecological process that affect recruitment, such as competition with invasive plant species (Ewers \& Didham 2006), and plant reproduction (see Aguilar et al. 2006 for review). Reproductive success may decrease in fragmented populations because plants may receive fewer flower visitors due to the decline in the richness and abundance of pollinators, modifications in

\footnotetext{
*Send correspondence to: Rosane Garcia Collevatti

Laboratório de Genética e Biodiversidade,

Departamento de Biologia Geral, Instituto de Ciências Biológicas,

Universidade Federal de Goiás - UFG

CP 131, CEP 74001-970, Goiânia, GO, Brasil

E-mail: rosanegc68@hotmail.com
}

species composition and limitation in movement among patches (e.g. Goverde et al. 2002). Fragmentation can also affect seed dispersal by changing abundance, richness or behavior of animal seed dispersers (Ghazoul 2005). Conversely, wind-dispersed plants are likely to be relatively immune from disturbances of landscapes and trees with small seeds dispersed by wind are favored over animal-dispersed trees with larger fruits (Born et al. 2008) and wind dispersal may be facilitated by fragmentation (Fore et al. 1992).

Monitoring genetic and demographic parameters provide insights into effective population size and gene flow, which are highly important for sound conservation and management programs. Following the framework proposed by Schwartz et al. (2006), different categories of genetic monitoring efforts, such as "diagnostic molecular markers for traditional population monitoring" and "monitoring population genetic parameters", may be guidelines to help direct discussions and encourage researches on population genetics for conservation and management. Despite methodological and operational difficulties, monitoring population genetic parameters, Category II in Schwartz et al. (2006) framework, is crucial because it is the raw material of evolution and affects the long-term population viability.

The seasonal savanna, known as cerrado sensu stricto, covers the Central and Centre-East Brazilian territory and displays high biodiversity, with more than 900 species of 
trees and shrubs, nearly $40 \%$ of which are endemic (Ratter et al. 2003). The entire Cerrado region has been intensively fragmented in the last decades because of agricultural expansion and less than $50 \%$ of its original area still remains (Klink \& Machado 2005), being thus an interesting region to start analyzing the effects of human occupation on plant population genetics and how this is related to life history characteristics.

Here we report the SGS of three species from Cerrado Biome with different life history traits. Our working hypothesis was that the self-incompatible and the wind dispersed species present no spatial genetic structure due to long distance pollen gene flow. Because of the relationship between SGS and ecological and life-history characteristics of plant species, which in turn is affected by habitat fragmentation and disturbance, it is possible to use these information to establish better management plans in natural populations or to delineate optimum sampling strategies for germplasm collections.

\section{Material and Methods}

\section{Studied species}

Caryocar brasiliense Camb. (Caryocaraceae), popularly known as "pequi", is a widely distributed cerrado tree species, locally distributed in well-delimited patches. Flowers are hermaphroditic and pollination is mainly performed by small glossophagine bats (Glossophaga soricinand and Anoura geoffroyi) (Gribel \& Hay 1993). The seeds are surrounded by a woody endocarp coated with a yellow fleshy mesocarp rich in oil and vitamin A, and may be dispersed by several wild animals such as the greater rhea (Rhea Americana) lobo-guará (Chrysocyon brachyurus), tapir (Tapirus terrestris), veado-catingueiro (Mazama guazoupira).

Tibouchina papyrus (Pohl) Toledo (Melastomataceae), known as "pau-papel", is endemic to outcrop quartzite and sandstone soils of cerrado rupestre of the Cerrado biome in altitudes above $900 \mathrm{~m}$. The species is self-compatible, flowers are hermaphroditic, and buzz-pollination is performed mainly by large bees, such as Xylocopa spp., Bombus spp. and Centris spp. (Montoro and Santos 2007). The very small seeds are wind dispersed.

Dipteryx alata Vogel (Fabaceae), known as "baru", is also widely distributed, but restricted to richer (euthrophic) and drained soils of seasonal savanna (cerradão). The species is hermaphroditic and self-incompatible (Oliveira and Sigrist 2008). Pollination is mainly performed by large (Xylocopa suspecta, Apidae) and medium-size (Halictidae) bees (Oliveira and Sigrist 2008). Seeds have a very woody endocarp with an edible nut that are eaten and dispersed by mammals, such as bats and monkeys.

Furthermore, fruits of C. brasiliense and seeds of D. alata are consumed in natura and are source of raw material for small and middle-sized food industries, playing an important role in economy of the inhabitants of Central Brazil.

\section{Populations and sampling}

A population of C. brasiliense in Água Limpa Experimental Station, Brasilia, DF ( $15^{\circ} 57^{\prime} 12.7^{\prime \prime} \mathrm{S}$ and $47^{\circ} 56^{\prime} 35.0^{\prime \prime} \mathrm{W}$ ) was studied. This Experimental Station has 4,000 ha of cerrado and is surrounded by other reserves, summing up almost 10,000 ha of preserved cerrado. In a patch of 8.3 ha within previously established permanent plots, all individuals were mapped and expanded leaves were sampled.

Tibouchina papyrus was sampled in a population in the "Serra da Natividade", Natividade, Southeast Tocantins ( $11^{\circ} 42^{\prime} 35^{\prime \prime} \mathrm{S}$ and $\left.47^{\circ} 43^{\prime} 24^{\prime \prime} \mathrm{W}\right)$. Serra da Natividade consists of outcrop quartzite and sandstone soils covered by cerrado rupestre, with $536 \mathrm{~m}$ of mean altitude. In a patch of 1.13 ha all adult individuals were mapped and expanded leaves were sampled.

The studied population of Dipteryx alata is localized in a seasonal savanna in euthrophic soil (cerradão), in Monte Alegre de Minas, West Minas Gerais ( $18^{\circ} 58^{\prime} 40.3^{\prime \prime} \mathrm{S}$ and $49^{\circ} 01^{\prime} 26^{\prime \prime} \mathrm{W}$ ). The landscape is dominated by a mosaic of small remnants of seasonal savanna surrounded by crop and pasture areas. In a small remnant of 2 ha of "cerradão" all adult individuals in a patch of 1.18 ha were mapped and expanded leaves were sampled.

\section{Spatial genetic structure and seed dispersal}

SGS analyses were based on polymorphism at microsatellite loci for one local population of each species (Table 1). A detailed description of genetic data used to genotype the populations are given elsewhere (Collevatti et al. 2010; Soares et al. 2009; Telles et al. in press). For all species, analyses were based only on the adult individuals. Populations were characterized for number of alleles per locus, expected heterozygosities under Hardy-Weinberg equilibrium (Nei 1978) and inbreeding coefficient $(f)$. Analyses were performed with FSTAT 2.9.3.2 (Goudet 2002).

To test the hypothesis that the self-incompatible species present no SGS, autocorrelation analyses were performed to verify kinship structure in the adult population and estimate seed dispersal based on the negative relationship between spatial distance and kinship due to isolation by distance (Wright 1943; Rousset 1997). Kinship (co-ancestry) was estimated using the Nason estimator $F_{\mathrm{ij}}$ (Loiselle et al. 1995). We computed $F_{\text {ij }}$ between all pairs of adult individuals using the software SPAGeDI (Hardy and Vekemans 2002). To test for kinship structure, the $F_{\mathrm{ij}}$ values were regressed on the natural logarithm of the spatial distance between individuals and $F_{\text {ij }}$ values were averaged over a set of distance classes (Table 1) and plotted against the distance classes. Standard errors were estimated by jackknife over loci. 
Table 1. Distance classes used for spatial genetic structure analyses for three species from Cerrado Biome, Caryocar brasiliense, Dipteryx alata and Tibouchina papyrus.

\begin{tabular}{llllllllllllllll}
\hline \multicolumn{1}{c}{ Species } & \multicolumn{11}{c}{ Distance classes $(\mathbf{m})$} \\
& $\mathbf{1}$ & $\mathbf{2}$ & $\mathbf{3}$ & $\mathbf{4}$ & $\mathbf{5}$ & $\mathbf{6}$ & $\mathbf{7}$ & $\mathbf{8}$ & $\mathbf{9}$ & $\mathbf{1 0}$ & $\mathbf{1 1}$ & $\mathbf{1 2}$ & $\mathbf{1 3}$ & $\mathbf{1 4}$ & $\mathbf{1 5}$ \\
\hline C. brasiliense & 5 & 10 & 15 & 20 & 25 & 30 & 35 & 40 & 45 & 50 & 100 & 200 & 300 & 400 & 500 \\
D. alata & 20 & 40 & 60 & 80 & 100 & 120 & 150 & 180 & 200 & 230 & 260 & 300 & 350 & 400 & \\
T. papyrus & 10 & 20 & 30 & 40 & 50 & 60 & 70 & 80 & 90 & 100 & 130 & 140 & 160 & 180 & 220 \\
\hline
\end{tabular}

Permutation tests $(10,000$ permutations) were performed to verify significance of kinship for each distance class and of regression.

The strength of the spatial genetic structure was quantified using the parameter $S_{\mathrm{p}}=b /\left(F_{1}-1\right)$, where $F_{1}$ is the average kinship coefficient between individuals of the first distance class and $b$ is the slope of the regression, following Vekemans and Hardy (2004). Seed dispersal was estimated based on the genetic neighborhood $(\mathrm{Nb})$ using the regression slope $b$ and the intra group $F_{\mathrm{ij}}\left(\mathrm{Nb}=\left(F_{1}-1\right) / b\right.$ or $\left.\mathrm{Nb}=1 / S_{\mathrm{p}}\right)$ following Vekemans and Hardy (2004). The distance frequency distributions of the three species were compared using Kolmogorov-Smirnof test (Sokal and Rolf 1995).

\section{Results}

Spatial distribution of adult individuals differed in the three species (Kolmogorov -Smirnov test $\mathrm{p}<0.001$ for the three comparisons). For $C$. brasiliense, the mean distance among adult trees was $168.38 \mathrm{~m}(\mathrm{SD}=87.62 \mathrm{~m})$. Most $(70 \%)$ individuals were distant from each other by less than $200 \mathrm{~m}$ and the pairwise distance distribution presented a median of $161 \mathrm{~m}$ (Figure 1). Dipteryx alata presented mean distance of $147.52 \mathrm{~m}(\mathrm{SD}=105.44 \mathrm{~m})$ and median of $117.74 \mathrm{~m}$ (Figure 1). Also, most individuals (70\%) were at distances lower than $200 \mathrm{~m}$. Tibouchina papyrus individuals were more clumped than the other two species, with median equal to $72.59 \mathrm{~m}$ and $70 \%$ of the individuals at distance lower than $113.41 \mathrm{~m}$ (Figure 1). Mean distance among adult individuals was $82.16 \mathrm{~m}(\mathrm{SD}=52.83 \mathrm{~m})$.

The studied population of Caryocar brasiliense presented high polymorphism and genetic diversity even though inbreeding coefficient was high and significantly different from zero (Table 2). Dipteryx alata and Tibouchina papyrus presented lower genetic diversity and allelic polymorphisms, but inbreeding coefficient were significantly negative (Table 2).

For C. brasiliense, autocorrelation analysis showed that kinship is slightly related to the logarithm of distance $\left(R^{2}=0.0098, \mathrm{p}<0.001\right)$. Kinship decreased strongly after the first distance class $(<5 \mathrm{~m}$, Figure $2 \mathrm{a})$, and significant until the class $3(10 \mathrm{~m})$. Dipteryx alata also showed significant relationship between kinship and distance $\left(R^{2}=0.0092, \mathrm{p}=0.05\right.$, Table 2$)$, with kinship was significantly autocorrelated up to the second class $(<40 \mathrm{~m}$, Figure $2 \mathrm{~b})$. For T. papyrus, spatial autocorrelation was significant up

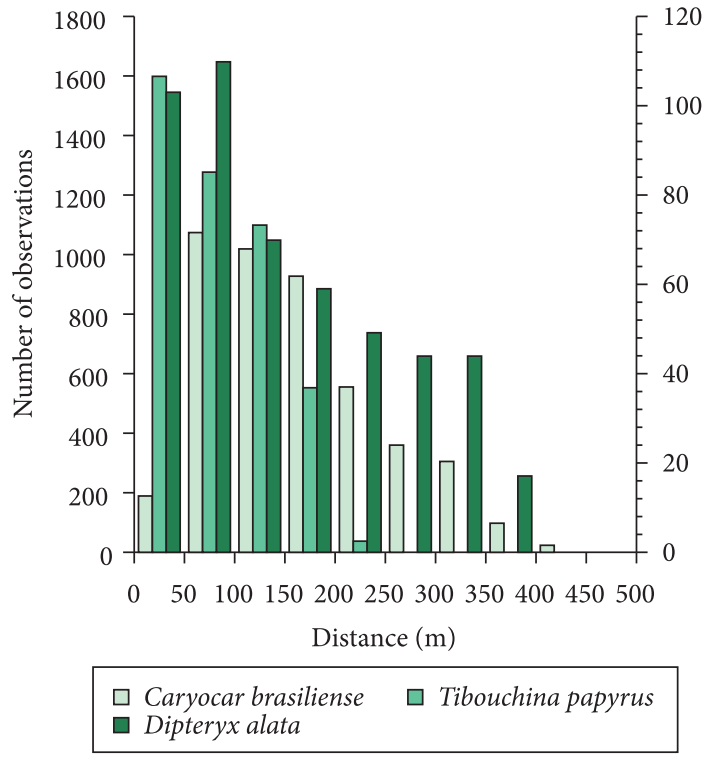

Figure 1. Pairwise distance distribution of the adult individuals in the population of a) C. brasiliense; b) Dipteryx alata; and c) T. papyrus, in Central Brazil.

to $10 \mathrm{~m}$ (class 1, Figure 2c) and kinship was weakly related to the logarithm of distance $\left(R^{2}=0.0017, \mathrm{p}=0.0241\right)$. Spatial genetic structure was weak for all species, with low levels of $S_{\mathrm{p}}$ (Table 2). The genetic neighborhood estimated from the spatial genetic structure of adults showed a larger neighborhood for T. papyrus than for C. brasiliense and D. alata (Table 2).

\section{Discussion}

Our results showed contrasting patterns of fine-scale spatial genetic structure for the three studied Cerrado species, which vary in their life histories. The seed dispersal syndrome seems to be decisive in determine the differences found in the present work. While mammal- dispersed species, C. brasiliense and D. alata, had similar patterns of SGS, with higher values of $S_{\mathrm{p}}$ than the wind dispersed species, so breeding system and pollination system could not account alone for the variation of SGS among species.

Breeding system did not affect the SGS because self-compatible species presented contrasting patterns, and the self-incompatible species, D. alata, had the strongest SGS, contrary to the expectations (see also Vekemans \& Hardy 
Table 2. Comparison of Spatial Genetic Structure (SGS) and genetic neighborhood among three cerrado species. N - number of individuals sampled; D - density (individuals per ha); $A$ number of alleles; SD - standard deviation; $H_{\mathrm{e}}$ - expected heterozygosity; $f$ - inbreeding coefficient; $F_{1}$ - intra group $F_{\mathrm{ij}} ; b$ - regression slope for the logarithmic relationship; $S_{\mathrm{p}}$ - strength of spatial genetic structure parameter; $N_{\mathrm{b}}$ - genetic neighborhood. For $f$, all values are significant, Bonferroni adjusted $\mathrm{P}$ value for a nominal level of $5 \%$ are: C. brasiliense, $\mathrm{p}=0.005 ; D$. alata, $\mathrm{p}=0.0125 ;$ T. papyrus, $\mathrm{p}=0.00625$. ${ }^{\star}$ All values are statistically significant for $\mathrm{p}=0.05$.

\begin{tabular}{|c|c|c|c|c|c|c|c|}
\hline Species & $\mathbf{N}$ & D Ind/ha & Breeding & Pollen & Seed dispersal & \multicolumn{2}{|c|}{ N loci } \\
\hline C. brasiliense & 101 & 12.2 & SC & bats & mammals $^{2}$ & 10 & \\
\hline D. alata & 32 & 27.0 & SI & bees & mammals & 4 & \\
\hline T.papyrus & 96 & 84.9 & SC & bees $^{1}$ & wind & 8 & \\
\hline Species & Mean $A \pm \mathrm{SD}$ & Mean $H_{e} \pm \mathrm{SD}$ & f & $\mathrm{F}_{1}^{*}$ & $\mathbf{b}^{*}$ & $S_{p}$ & $\mathrm{Nb}$ \\
\hline C. brasiliense & $16.1 \pm 3.281$ & $0.874 \pm 0.041$ & $0.131 \pm 0.112$ & $0.149 \pm 0.012$ & -0.0099 & 0.0116 & 86.20 \\
\hline D. alata & $2.7 \pm 0.500$ & $0.451 \pm 0.059$ & $-0.224 \pm 0.155$ & $0.059 \pm 0.057$ & -0.0162 & 0.0172 & 58.09 \\
\hline T. papyrus & $2.0 \pm 0.756$ & $0.295 \pm 0.218$ & $-0.168 \pm 0.073$ & $0.032 \pm 0.014$ & -0.0088 & 0.0085 & 118.05 \\
\hline
\end{tabular}

aSC: self-compatible; SI: self-incompatible; ${ }^{1}$ buzz pollination; ${ }^{2}$ may also be dispersed by Rhea Americana.

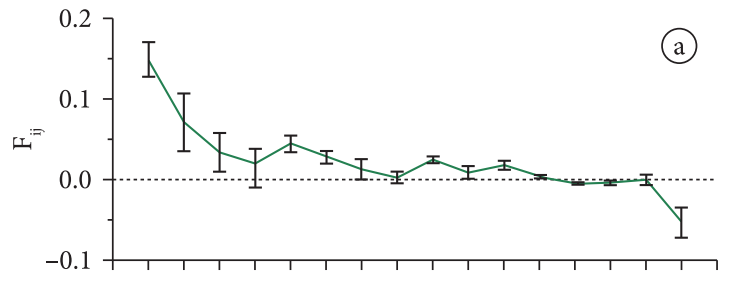

$\begin{array}{llllllllllllllllll}0 & 1 & 2 & 3 & 4 & 5 & 6 & 7 & 8 & 9 & 10 & 11 & 12 & 13 & 14 & 15 & 16\end{array}$

Distance class

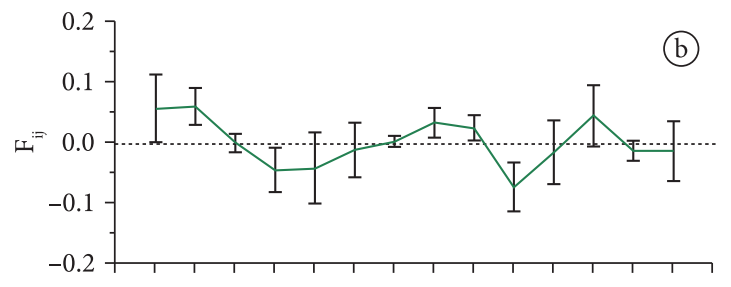

$\begin{array}{lllllllllllllllll}0 & 1 & 2 & 3 & 4 & 5 & 6 & 7 & 8 & 9 & 10 & 11 & 12 & 13 & 14 & 15\end{array}$

Distance classes

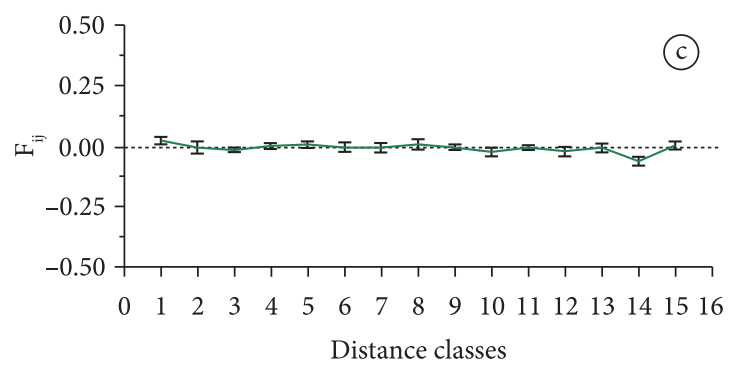

Figure 2. Relationship between kinship $\left(\mathrm{F}_{\mathrm{ij}} \pm \mathrm{SE}\right)$ and distance for adult individuals of C. brasiliense, D. alata and T. papyrus in Central Brazil. a) C. brasiliense; b) D. alata; and c) T. papyrus. See Table 1 for distance classes.

2004). In addition, the self-incompatible species presented negative inbreeding coefficient, showing an alogamous mating system (Wright 1965) or excess of heterozygous individuals due to balancing selection (Lewontin 1985). Caryocar brasiliense, a self-compatible species, presented high inbreeding coefficient (0.131), in contrast with T. papyrus, which is also self-compatible, but with highly negative inbreeding coefficient (-0.168). Although C. brasiliense is bat pollinated, which may potentially fly long distances and promote long distance pollen flow, the studied population presents high rate of self-pollination (see Collevatti et al. 2010). The high density and clumped spatial distribution of C. brasiliense may promote high residence time of pollinators within an individual tree and within a patch of flowering plants causing high proportion of self-pollination and high probability of full-sibship within progeny arrays (Collevatti et al. 2010). The wind seed dispersal system of T. papyrus may have counteracted the high population density and self-compatible system, causing a weaker SGS.

Although the spatial genetic structure was weak for the three studied species, compared to other tree species (see Vekemans \& Hardy 2004 for a review), the species with mammal dispersed seeds, C. brasiliense and D. alata presented a slightly higher $S_{\mathrm{p}}$ than the wind dispersed species, T. papyrus. $S_{\mathrm{p}}$ is expected to be higher in predominantly selfing than in self-incompatible species, with intermediate values for self-compatible species with mixed-mating systems (see Vekemans and Hardy 2004 for a review). Wind may promote long distance seed dispersal (Horn et al. 2001), especially in open habitats, such as cerrado "rupestre".

Maximizing genetic diversity conservation and sampling for germplasm collection may include individuals from different patches that can be estimated by SGS autocorrelation analyses of each species, as shown here (see also Diniz-Filho and Telles 2002). Accordingly, the design of reserves and the sampling for germplasm collections should consider the life history traits and the SGS particular of each species.

Our results suggest that the three species may be highly affected by fragmentation and disturbance of their natural habitats due to life history characteristics, leading to significant spatial genetic structure. Wind-dispersed plants are likely to be relatively immune from disturbances of landscapes (Ghazoul 2005) because wind dispersal may be facilitated by fragmentation and trees with small seeds dispersed by wind are favored over animal-dispersed trees with large fruits (Fore et al. 1992; Cordeiro \& Howe 2003). Nevertheless, T. papyrus is a rare and endemic species of 
sandstone outcrop habitat, which is highly unstable and sufers high levels of disturbance caused by fire during the dry season and sandstone and quartzite disruption, mainly during the rainy season. These disturbances may be highly variable among local habitats and may cause sudden modifications in population size. In fact, population size and density in T. papyrus is very variable in space and throughout the years (M. P. C. Telles, personal observation). Hence, despite wind dispersal, weak SGS and negative inbreeding coefficient, high census size compared to genetic neighborhood, this may be the most threaten species out of the three studied species, because of rarity, endemism and the instability of its habitat.

The studied population of D. alata has lower census size than the genetic neighborhood. Thus, this population may be threat due to the deleterious effects of genetic drift. Besides, the population is in a small and isolated fragment of "cerradão" in a roadside, which may impose constrains population recovery. Conversely, Caryocar brasiliense population is situated in a reserve but presented high inbreeding coefficient, with low seed and pollen dispersal distance (Collevatti et al. 2010). Thus, fragmentation may favor the isolation among C. brasiliense populations, decreasing population size and increasing inbreeding, ultimately resulting in local extinction.

Therefore, the maintenance of non-isolated populations in many and large preserved areas may be necessary for species viability in Cerrado biome, providing means for gene flow by pollen and seed. Additionally, these areas play an important role in the maintenance of small populations in highly disturbed areas, as a source of pollen and seeds, and contribute to the viability of pollinator and disperser populations.

\section{Acknowledgements}

This project was partially supported by a PRONEX project from CNPq/SECTEC-GO (Proc. No. 23234156) and CNPq "Universal" project to MPCT (471492/2007-8) for establishing conservation priorities in the Cerrado region. MPCT and RGC overall research program in Molecular Ecology has been continuously supported by CNPq and CAPES grants and fellowships which we gratefully acknowledge. We wish to thank Professor José Alexandre F. Diniz-Filho for helpful comments in the manuscript.

\section{References}

Aguilar R et al., 2006. Plant reproductive susceptibility to habitat fragmentation: review and synthesis through a meta-analysis. Ecology Letters, 9: 968-980.

Born C et al., 2008. Small-scale spatial genetic structure in the Central African rainforest tree species Aucoumea klaineana: a stepwise approach to infer the impact of limited gene dispersal, population history and habitat fragmentation. Molecular Ecology, 17: 2041-2050.

Collevatti RG et al., 2010. Short-distance pollen dispersal and high self-pollination in a bat-pollinated neotropical tree. Tree Genetics \& Genomes, DOI 10.1007/s11295-010-0271-4.
Cordeiro NJ \& Howe HF, 2003. Forest fragmentation severs mutualism between seed dispersers and an endemic African tree. Proceedings of the National Academy of Sciences, 100: 14052-14056.

Diniz-Filho JAF \& Telles MPC, 2002. Spatial autocorrelation analysis and the identification of operational units for conservation in continuous populations. Conservation Biology, 16: 924-935.

Ewers RM \& Didham RK, 2006. Confounding factors in the detection of species responses to habitat fragmentation. Biological Reviews, 81: 117-142.

Fore SA et al., 1992. Genetic structure after forest fragmentation: a landscape ecology perspective on Acer saccharum. Canadian Journal of Botany, 70: 1659-1668.

Ghazoul J, 2005. Pollen and seed dispersal among dispersed plants. Biological Reviews, 80: 413-443.

Goudet J, 2002. FSTAT, a program to estimate and test gene diversities and fixation indices. Version 2.9.3.2. Available from: http://www.unil.ch/izea/softwares/fstat.html.

Goverde M et al., 2002. Small-scale habitat fragmentation effects on pollinator behavior: experimental evidence from the bumblebee Bombus veteranus on calcareous grasslands. Biological Conservation, 104: 293-299.

Gribel R \& Hay JD, 1993. Pollination ecology of Caryocar brasiliense (Caryocaraceae) in Central Brazil cerrado vegetation. Journal of Tropical Ecology, 9:199-211.

Hardy OJ \& Vekemans X, 2002. SPAGeDi: a versatile computer program to analyse spatial genetic structure at the individual or population levels. Molecular Ecology Notes, 2: 618-620.

Hardy OJ et al., 2006. Fine-scale genetic structure and gene dispersal inferences in 10 Neotropical tree species. Molecular Ecology, 15: 559-571.

Horn HS, Nathan R \& Kaplan SR, 2001. Long-distance dispersa of tree seeds by wind. Ecological Research, 16: 877-885.

Jones FA et al., 2005. A genetic evaluation of seed dispersal in the Neotropical tree Jacaranda copaia (Bignoniaceae). The American Naturalist, 166: 543-555.

Klink CA \& Machado RB, 2005. Conservation of the Brazilian Cerrado. Conservation Biology, 19: 707-713.

Lewontin RC, 1985. Population genetics. Annual Review of Genetics, 19: 81-102.

Loiselle BA et al., 1995. Genetic structure of a tropical understorey shrub, Psychotria officinalis (Rubiaceae). American Journal of Botany, 82:1420-1425.

Montoro GR \& Santos ML, 2007. Fenologia e Biologia Reprodutiva de Tibouchina papyrus (Pohl) Toledo (Melastomataceae) no Parque Estadual da Serra dos Pireneus, Goiás. Revista de Biologia Neotropical, 4:21-29.

Nei M, 1978. Estimation of average heterozygosity and genetic distance from a small number of individual. Genetics, 89:583-590.

Oliveira MIB \& Sigrist MR, 2008. Fenologia reprodutiva, polinização e reprodução de Dipteryx alata Vogel (Leguminosae-Papilionoideae) em Mato Grosso do Sul. Revista Brasileira de Botânica, 31:195-207. 
Ratter JA, Bridgewater S \& Ribeiro JF, 2003. Analysis of the floristic composition of the Brazilian Cerrado vegetation: Comparison of the woody vegetation of 376 areas. Edinburgh Journal of Botany, 60:57-109.

Rousset F, 1997. Genetic differentiation and estimation of gene flow from F-statistics under isolation by distance. Genetics, 145:1219-1228.

Soares TN, 2009. Estrutura genética populacional e fluxo gênico em Dipteryx alata Vogel (Fabaceae) no Cerrado. [Tese de Doutorado]. Goiânia: Escola de Agronomia e Engenharia de Alimentos, Universidade Federal de Goiás.

Sokal RR \& Rohlf F, 1995. Biometry: the principles and practices of statistics in biological research. $3^{\text {rd }}$ ed. New York: Freeman.

Schwartz MK, Luikart G \& Waples RS, 2006. Genetic monitoring as a promising tool for conservation and management. Trends in Ecology and Evolution, 22:25-33.
Telles MPC, Peixoto FP, Lima JS, Resende LV, Brondani RPV, Walter MEMT \& Collevatti RG, in press. Development of Microsatellite Markers for the Neotropical Endangered Tree Species Tibouchina papyrus (Melastomataceae). Conservation Genetics Resources.

Vekemans X \& Hardy OJ, 2004. New insights from fine-scale spatial genetic structure analyses in plant populations. Molecular Ecology, 13: 921-935.

Wright S, 1943. Isolation by distance. Genetics, 28:114-138.

Wright S, 1965. The interpretation of population structure by F-statistics with special regard to system of mating. Evolution, 19:395-420.

Received: March 2010

First Decision: April 2010

Accepted: April 2010 